\title{
Photosynthetic behavior, growth and essential oil production of Melissa officinalis L. cultivated under colored shade nets
}

\author{
Graziele C. Oliveira ${ }^{1}$, Willyam L. Vieira ${ }^{2}$, Suzana C. Bertolli ${ }^{3}$, and Ana Claudia Pacheco ${ }^{1 *}$
}

\section{ABSTRACT}

The modulation of light is of importance during cultivation of medicinal plants to obtain desirable morphological and physiological changes associated with the maximum production of active principles. This study aimed to evaluate the effect of the light spectrum transmitted by colored shade nets on growth, essential oil production and photosynthetic behavior in plants of lemon balm (Melissa officinalis L.) Plants were cultivated in pots for 4-mo under black, red, and blue nets with $50 \%$ shading, and full sunlight exposure. Biometric and anatomical variables, essential oil yield, global solar radiation, photon flux density, chlorophyll content, and gas exchange parameters were measured in $M$. officinalis leaves. The results showed that despite being considered a partial shade plant, this species is able to adapt to full sunlight conditions without increasing biomass production. The spectral changes provided by colored shade nets did not caused any noticeable change in leaf anatomy of M. officinalis. However, the use of blue net resulted in increments of $116 \%$ in plant height, $168 \%$ in leaf area, $42 \%$ in chlorophyll content and $30 \%$ in yield of essential oil in lemon balm plants. These plant's qualities make the use of blue net a cultivation practice suitable for commercial use.

Key words: Medicinal plant, development, gas exchange, leaf anatomy.
${ }^{1}$ Universidade do Oeste Paulista, Faculdade de Ciências Agrárias, Presidente Prudente, 19067-175, São Paulo, Brasil.

*Corresponding author (anaclau@unoeste.br)

${ }^{2}$ Universidade do Oeste Paulista, Faculdade de Ciências Biológicas, Presidente Prudente- São Paulo, Brasil.

${ }^{3}$ Universidade Estadual Paulista "Júlio de Mesquita Filho", Instituto de Biociências, Rio Claro, 13506-900, São Paulo, Brasil.

Received: 19 March 2015

Accepted: 31 August 2015

doi:10.4067/S0718-58392016000100017

\section{INTRODUCTION}

Lemon balm (Melissa officinalis L., Lamiaceae) is a medicinal plant of great economic importance due to its proved therapeutic properties and their inclusion in the Pharmacopoeia of different countries (Weitzel and Petersen, 2010). In recent years, due to the new commercial interest in natural products, the increased demand for the production of plant extracts of this species has required the development of intensive cultivation techniques which might favor a faster growth and contribute to the productivity of plantderived products.

The use of shade nets with different colors allows physical plant protection combined with promotion of the physiological responses regulated by light (Martins et al., 2008), since these nets are able to modify both the quantity and quality of solar radiation transmitted. Thus, photoselective nettings have been developed in different colors to alter the spectrum of transmitted light, with the blue and red nets exhibiting peaks of transmittance in the blue-green $(400-540 \mathrm{~nm})$ region and in the red region $(590 \mathrm{~nm})$, respectively (Oren-Shamir et al., 2001).

The use of colored nets has been related to the production of essential oil, growth and biomass allocation, pigments content, and leaf anatomy (Brant et al., 2009; 2010; 2011). However, there are few reports on the effect of the quantity and quality of light on the photosynthetic capacity in M. officinalis. Cassol et al. (2007) examined the absorption characteristics of light energy and photosynthetic parameters in lemon balm plants when cultivated under reduced light conditions. According to these authors, net photosynthesis was negatively influenced by shading, and the biochemical steps of photosynthesis proved to be more sensitive to the effects of light in this species.

Taking into consideration that leaves have high plasticity to adjust their anatomy and physiology in response to different light conditions that alter plant development and secondary metabolites production, the aim of this study was to analyze the changes in growth, leaf anatomy, photosynthetic behavior, and essential oil production of Melissa officinalis cultivated under different colored shade nets. 


\section{MATERIALS AND METHODS}

\section{Study site and plant material}

The experiment was conducted from May to December 2012

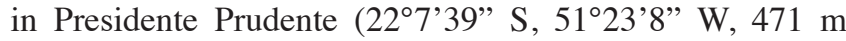
a.s.l.), São Paulo, Brazil. According to Köppen classification, the regional climate is type Aw mesothermal with hot summers and dry winters (Brazil, 1992). Climatological data from Presidente Prudente are shown in Table 1.

Lemon balm seeds were planted in a nursery in a seed bed formed with a mixture of sand and commercial substrate Bioplant (Bioplant Agrícola) $(1: 1 \mathrm{v} / \mathrm{v})$. The seedlings were grown under $50 \%$ shading for $60 \mathrm{~d}$ and then were transplanted to $5 \mathrm{~L}$ pots containing soil, sand, and cattle manure in a 2:1:1 ratio $(\mathrm{v} / \mathrm{v} / \mathrm{v})$ for the shading experiment. Plants were maintained in the nursery, where they received full sunlight or were under shade. For the shade treatments, light was artificially reduced using red, blue, and black nets (ChromatiNet-Polysack Industries, Nir Yitzhak, Israel) allowing 50\% shade. Plants were cut twice $(10 \mathrm{~cm}$ above soil surface) during the growth period, the first cut at $50 \mathrm{~d}$ after transplanting (DAT) and the second after regrowth at 120 DAT. Irrigation was manually performed three times a week to maintain high soil humidity and a new fertilization was done with cattle manure after the first cut (125 g per pot).

\section{Photosynthetic characteristics and chlorophyll content}

The measurements of radiation were made under clear sky conditions during 3 consecutive days at 08:00, 13:00 and 18:00 h. Solar radiation $\left(\mathrm{R}_{\mathrm{g}}, \mathrm{W} \mathrm{m} \mathrm{m}^{-2}\right)$ was determined by a pyranometer (Li-200R, LI-COR, Lincoln, Nebraska, USA). Measurements of photosynthetic photon flux density (PPFD, $\mu$ mol photons $\mathrm{m}^{-2} \mathrm{~s}^{-1}$ ) were made using a quantometer (LQ model 250A, LI-COR). The estimated amount of incident radiation reaching the top of the plants, which was probably used in photosynthesis realization, was calculated by the $\mathrm{Rg} / \mathrm{PPFD}$ ratio.

Photosynthetic light-response curves (curves A/PPFD, where A corresponds to the net $\mathrm{CO}_{2}$ assimilation) were created by measuring the steady rates at 40 DAT using five

Table 1. Climatological data of Presidente Prudente, São Paulo, during the experimental period (May-December 2012).

\begin{tabular}{|c|c|c|c|c|}
\hline \multirow[b]{2}{*}{ Month } & \multicolumn{3}{|c|}{ Temperature of the air $\left({ }^{\circ} \mathrm{C}\right)$} & \multirow{2}{*}{$\frac{\text { Precipitation }}{\mathrm{mm}}$} \\
\hline & Minimum & Maximum & Mean & \\
\hline May & 15.7 & 24.2 & 21.7 & 109.6 \\
\hline June & 14.3 & 25.2 & 20.4 & 284.3 \\
\hline July & 13.1 & 25.4 & 20.6 & 23.7 \\
\hline August & 20.5 & 25.3 & 23.7 & - \\
\hline September & 16.1 & 31.2 & 24.6 & 116.1 \\
\hline October & 18.3 & 31.5 & 26.3 & 22.0 \\
\hline November & 20.8 & 30.4 & 25.8 & 107.5 \\
\hline December & 22.9 & 31.4 & 28.0 & 297.6 \\
\hline
\end{tabular}

Source: Center for Weather and Climate Research Applied to Agriculture (CEPAGRI/UNICAMP). plants per treatment (one leaf per plant). All A/PPFD curves were estimated from 09:00 to 13:00 h on subsequent days using measurements obtained from healthy, fully expanded leaves. Inside the leaf chamber of an infrared gas analyzer (Li-6400XTR, LI-COR) temperature was adjusted to $30{ }^{\circ} \mathrm{C}$, $\mathrm{CO}_{2}$ concentration was $380 \mu \mathrm{mol} \mathrm{mol}{ }^{-1}$, and vapor pressure deficit was maintained at $1.5 \mathrm{kPa}$ with a dew point generator (model Li-610, LI-COR) connected to the leaf chamber. Light was provided by LEDs emitting in the blue-red spectrum connected to the Li-6400XTR sampling chamber. Variables obtained from A/PPFD curves were maximum $\mathrm{CO}_{2}$ assimilation $\left(A_{\max }\right)$, light compensation $\left(P_{\text {com }}\right)$, and saturation $\left(P_{\text {sat }}\right)$ points calculated when A reaches $90 \% \mathrm{~A}_{\max }$, apparent quantum efficiency (AQE) corresponds to the slope of the initial linear region of the curve $\mathrm{A} / \mathrm{PPFD}$, transpiration (E), stomatal conductance $\left(g_{s}\right)$ obtained from the saturation point of photosynthesis at light, and leaf dark respiration $\left(R_{d}\right)$ when PPFD $=0 \mu$ mol photons $\mathrm{m}^{-2} \mathrm{~s}^{-1}$.

Chlorophyll content index (CCI) was estimated using a chlorophyll content meter (CCM-200 Opti-Sciences, Hudson, New Hampshire, USA) based on the absorbance of the intact leaf at two wavelengths (660 and $950 \mathrm{~nm})$. Measurements were made on three randomly selected and completely expanded leaves per plant in each treatment at the time of the first cut (50 DAT).

\section{Plant growth and leaf anatomy}

Total leaf area (LA), dry mass (DM) of leaves, stems, roots, and whole plant, root/shoot ratio, specific leaf mass, and leaf weight ratio (LWR) were evaluated in two periods (50 and 120 DAT) using five plants per treatment. Plant height was evaluated only at 120 DAT, when plants were standardized by the first cut. Leaf area was measured using a leaf area meter (LI-3000A, LI-COR). After measuring the plants, they were placed into a forced air circulation oven at $60{ }^{\circ} \mathrm{C}$ until constant mass. The leaf weight ratio was determined as leaf $\mathrm{DM} /$ total DM and specific leaf area (SLA) was determine as LA/leaf DM.

For leaf anatomical analysis, five leaves were randomly collected from plants in each treatment at 50 DAT. A sample of approximately $100 \mathrm{~mm}^{2}$ was detached from the median region of the leaf under an optical microscope. The samples were fixed in formaldehyde-acetic acid (FAA) $50 \%$ (Johansen, 1940) and preserved in 70\% ethanol. Semipermanent slides were mounted from cross sections stained with toluidine blue and mounted with glycerol (O'Brien et al., 1965). The thickness of adaxial and abaxial epidermis, palisade, and spongy parenchyma were measured in crosssections of the median region of leaves. The total number of xylem conduits and the diameter of the 10-15 widest conduits per section were evaluated in the leaf midrib using the ImageJ software (Research Services Branch, National Institute of Mental Health, Bethesda, Maryland, USA). For venation density, sections from the leaves middle portion were collected, clarified following the procedure described by Fonseca et al. (2007) and then analyzed using light 
microscopy. Images were taken and processed as above. The minor vein densities ( $4^{\text {th }}$ and higher order) were calculated as the total length of the veins per unit of leaf area.

\section{Essential oil content}

Ten grams of leaves dried in a forced air circulation oven at $35{ }^{\circ} \mathrm{C}$ were extracted in a Clevenger apparatus. Given the mass of oil obtained after removal of the salt (anhydrous magnesium sulfate) and evaporation of the solvent (dichloromethane), the percentage of essential oil content in leaves was determined by: $\mathrm{T}(\%)=$ weight of oil $(\mathrm{g}) / 10 \mathrm{~g} \times$ 100. The oil yield was calculated by the formula (Brant et al., 2009): $\mathrm{R}=$ total dry weight of leaves/plant $(\mathrm{g}) \times$ weight of oil obtained $(\mathrm{g}) / 10 \mathrm{~g}$.

\section{Data analysis}

The experimental design for the shading experiment was a completely randomized design with four replicates of five plants each (20 plants per treatment). ANOVA was performed on all experimental data using the statistical program Sisvar (Ferreira, 2000) and mean differences were assessed at a 5\% level by Tukey's test.

\section{RESULTS AND DISCUSSION}

The red, blue, and black shade nets as compared to full sunlight resulted in a reduction in global radiation $\left(R_{g}\right)$ of $36 \%, 60 \%$, and $64 \%$, respectively (Table 2). Likewise, photosynthetic photon flux density (PPFD) in the blue and black nets decreased approximately $65 \%$ when compared to full sunlight, while for red net the reduction was 59\%. The black net presented the lowest value of the ratio $\mathrm{R}_{\mathrm{g}} / \mathrm{PPFD}$, i.e. the amount of incident radiation, which is probably used in photosynthesis realization. In contrast, the red net showed the highest rate of this relationship, indicating a small proportion of photosynthetically active radiation (PAR) in relation to the amount of global radiation.

Regarding the gas exchange parameters, we found that the apparent quantum efficiency (AQE) did not differ between treatments despite the lower values of AQE for the red and blue nets compared to full sunlight, possibly due to the reduction in PPFD (Table 3 ).

Plants growing under intense radiation have higher $\mathrm{C}$ assimilation and dark respiration than plants in shaded conditions, either to maintain their structures of greater

Table 2. Mean values of global radiation $\left(R_{g}\right)$ and photosynthetic photon flux density (PPFD) under different colored shade nets.

\begin{tabular}{lrrrc}
\hline & Full sun & Black & Blue & Red \\
\hline $\mathrm{R}_{\mathrm{g}}, \mathrm{W} \mathrm{m}{ }^{-2}$ & 436.34 & 156.80 & 174.16 & 275.94 \\
PPFD, $\mu$ mol photons $\mathrm{m}^{-2} \mathrm{~s}^{-1}$ & 786.70 & 271.96 & 238.33 & 317.37 \\
$\mathrm{R}_{\mathrm{g}} / \mathrm{PPFD}$ & 0.55 & 0.57 & 0.73 & 0.86 \\
\hline
\end{tabular}

Table 3. Photosynthetic traits derived from net $\mathrm{CO}_{2}$ assimilation (A)/photosynthetic photon flux density (PPFD) curves of Melissa officinalis plants grown under different colored nets.

\begin{tabular}{|c|c|c|c|c|c|}
\hline & Full sun & Black & Blue & Red & $\mathrm{CV}(\%)$ \\
\hline $\mathrm{AQE}$ & $0.07 \mathrm{a}$ & $0.06 \mathrm{a}$ & $0.05 \mathrm{a}$ & $0.05 \mathrm{a}$ & 13.00 \\
\hline$R d, \mu \mathrm{mol} \mathrm{CO} 2 \mathrm{~m}^{-2} \mathrm{~s}^{-1}$ & $1.80 \mathrm{ab}$ & $2.29 \mathrm{a}$ & $1.16 \mathrm{ab}$ & $0.80 \mathrm{~b}$ & 42.15 \\
\hline$A_{\max }, \mu \mathrm{mol}$ photons $\mathrm{m}^{-2} \mathrm{~s}^{-1}$ & $16.70 \mathrm{a}$ & $15.58 \mathrm{ab}$ & $11.34 b$ & $11.93 b$ & 15.76 \\
\hline$P_{\text {com }}, \mu$ mol photons $\mathrm{m}^{-2} \mathrm{~s}^{-1}$ & $28.55 \mathrm{a}$ & $24.16 \mathrm{a}$ & $20.44 a$ & $15.55 \mathrm{a}$ & 37.68 \\
\hline$P_{s a t}, \mu \mathrm{mol}$ photons $\mathrm{m}^{-2} \mathrm{~s}^{-1}$ & $589.51 \mathrm{a}$ & $574.74 \mathrm{a}$ & $601.57 \mathrm{a}$ & $532.30 \mathrm{a}$ & 28.49 \\
\hline 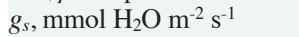 & $0.25 \mathrm{a}$ & $0.23 \mathrm{a}$ & $0.15 \mathrm{a}$ & $0.13 \mathrm{a}$ & 34.91 \\
\hline $\mathrm{E}, \mathrm{mmol} \mathrm{H}_{2} \mathrm{O} \mathrm{m}^{-2} \mathrm{~s}^{-1}$ & 4.15ab & $5.84 \mathrm{a}$ & $4.17 \mathrm{ab}$ & $2.33 b$ & 33.50 \\
\hline $\mathrm{CCI}$ & $13.44 b$ & $15.90 \mathrm{~b}$ & $19.19 \mathrm{a}$ & $14.06 \mathrm{~b}$ & 9.40 \\
\hline
\end{tabular}

Distinct letters in the row indicate significant differences according to Tukey's test $(\mathrm{P} \leq 0.05)$.

AQE: Apparent quantum efficiency, $R d$ : dark respiration, $A_{\max }$, maximum $\mathrm{CO}_{2}$ assimilation-; $P_{\text {com }}$ : compensation (-), $P_{\text {sat }}$ : saturation points of photosynthesis to light, $g_{s}$ : stomatal conductance, E: leaf transpiration, CCI: chlorophyll content index.

energy cost for growth and biomass increment (Lichtenthaler et al., 1981; Lichtenthaler and Burkart, 1999). However, our results indicate that lemon balm plants under full sunlight had higher maximum $\mathrm{CO}_{2}$ assimilation $\left(A_{\max }\right)$, with no significant increase in $\mathrm{R}_{\mathrm{d}}$ (Table 3 ) compared to the treatments under nets, which demonstrates its adaptation to a higher radiation condition, despite being considered a partial shade species.

Plants grown under black net had higher $R_{d}$, which is an indication that there was a greater expenditure of $\mathrm{C}$ for the process of respiration. Plants under the red and blue nets showed lower photosynthetic capacity as well as lower rates of dark respiration, suggesting that both the assimilation process and $\mathrm{C}$ consumption were affected by such treatments.

In the study of Cassol et al. (2007) with M. officinalis and Mentha xpiperita L. a $50 \%$ reduction in luminance caused a decrease of $57 \%$ and $60 \%$ of $\mathrm{CO}_{2}$ assimilation rate, respectively. According to the authors, this reduction in net photosynthesis was caused by a lower energy production by photochemical apparatus, since the biochemical efficiency of photosynthesis was more sensitive to the effect of light on the two species studied.

Here, we did not observe differences between treatments in relation to the compensation point and light saturation point of photosynthesis (Table 3 ). Valladares and Niinemets (2008) show the standard responses of light and shade on the plant physiology and suggest that a higher light compensation point and dark respiration in plants grown under full sunlight are common when compared to shaded plants. Although an increased $R_{d}$ was observed for plants grown under the black net in relation to the red counterpart, no changes in $\mathrm{P}_{\text {com }}$ and $\mathrm{P}_{\text {sat }}$ indicate that the increase in $\mathrm{C}$ consumption by respiration is not necessarily accompanied by an increase in the amount of radiation.

Small changes (nonsignificant) in stomatal conductance $\left(g_{s}\right)$ and transpiration (E) were observed when comparing lemon balm plants grown under the colored nets in relation to full sunlight plants (Table 3). The control of gas exchange by the stomata is essential for the maintenance of photosynthetic activity and hydration of tissues (Oliver et al., 2009; Blum, 2009). Therefore, our results indicate that the photosynthetic decrease under colored net treatments was not due to stomatal 
conductance, which could have reduced the $\mathrm{CO}_{2}$ diffusion from atmosphere to inside the leaf, but most likely due to the lower radiation provided by the nets.

The highest content of chlorophyll in leaves (increment of $42 \%$ in relation to full sunlight plants) was found in plants grown under blue net (Table 3). The total chlorophyll content was also significantly higher in plants of Mikania laevigata grown under the blue net (Souza et al., 2011). This difference is probably more the effect of light quality than quantity, since in the black and red nets this same response was not detected. According to Poudel et al. (2008), blue light exerts a positive and coordinated influence during development of chloroplasts and synthesis of chlorophyll in plant cells, which may explain the chlorophyll increase under this net color in our experiment.

Few biometric parameters showed significant differences between treatments in the first cut at 50 DAT (Table 4). Plants in full sunlight showed similar development to those subjected to shading, highlighting again the potential for adaptation of $M$. officinalis to intense irradiance. Compared to full sunlight, black and blue nets positively influenced the values of stem DM. The reduction in the root/shoot ratio in plants subjected to black net indicates that there was less biomass allocation to roots in relation to the other treatments (Table 4).

In the second cut (120 DAT), dry mass of leaves and stems was higher in plants subjected to colored nets when compared with the treatment of full sunlight, but without differences among the nets (Table 5). Furthermore, we observed a significant increase of the values for leaf area (LA), leaf weight ratio (LWR) and plant height in plants subjected to blue net $(168 \%, 12.5 \%$ and $116 \%$, respectively) compared with plants grown under full sunlight (Table 4). The increase in LA caused by the blue net was similar to that observed in Artemisia vulgaris L. (Oliveira et al., 2009), Ocimum gratissimum L. (Martins et al., 2008) and M. laevigata (Souza et al, 2011). Increasing LA is a common strategy used by plants under lower levels of irradiance, as those produced by the blue net (lowest PPFD values, Table 2), to maximize the available area for capturing light energy. In addition, the increase of the photosynthetic surface can compensate the low

Table 4. Dry mass parameters and essential oil from the first cut (50 DAT) of Melissa officinalis plants under different colored nets.

\begin{tabular}{|c|c|c|c|c|c|}
\hline & Full sun & Black & Blue & Red & $\mathrm{CV}(\%)$ \\
\hline $\mathrm{LA}, \mathrm{dm}^{2}$ & $16.98 \mathrm{a}$ & $18.60 \mathrm{a}$ & $24.06 \mathrm{a}$ & $16.69 \mathrm{a}$ & 19.16 \\
\hline Leaf DM, g & $4.71 \mathrm{a}$ & $4.67 \mathrm{a}$ & $5.85 \mathrm{a}$ & $5.01 \mathrm{a}$ & 19.12 \\
\hline Stem DM, g & $2.13 \mathrm{c}$ & $3.79 \mathrm{ab}$ & $4.18 \mathrm{a}$ & $2.68 b c$ & 21.60 \\
\hline Root DM, g & $8.71 \mathrm{ab}$ & $4.06 \mathrm{c}$ & $10.55 \mathrm{a}$ & $7.12 \mathrm{bc}$ & 19.14 \\
\hline Total DM, g & $15.55 \mathrm{ab}$ & $12.53 b$ & $20.60 \mathrm{a}$ & $14.82 \mathrm{~b}$ & 16.15 \\
\hline LWR, $\mathrm{g} \mathrm{g}^{-1}$ & $0.30 \mathrm{~b}$ & $0.37 \mathrm{a}$ & $0.28 \mathrm{~b}$ & $0.34 \mathrm{ab}$ & 8.33 \\
\hline Root/Shoot, $\mathrm{g} \mathrm{g}^{-1}$ & $1.30 \mathrm{a}$ & $0.48 b$ & $1.07 \mathrm{a}$ & $0.94 \mathrm{a}$ & 20.37 \\
\hline SLM, $\mathrm{g} \mathrm{dm}^{-2}$ & $0.28 \mathrm{a}$ & $0.25 \mathrm{a}$ & $0.24 \mathrm{a}$ & $0.23 \mathrm{a}$ & 10.45 \\
\hline Essential oil content, \% & $0.27 \mathrm{a}$ & $0.21 \mathrm{a}$ & $0.39 \mathrm{a}$ & $0.40 \mathrm{a}$ & 25.13 \\
\hline $\mathrm{OY}, \mathrm{g}$ plant $^{-1}$ & $0.012 \mathrm{a}$ & $0.011 \mathrm{a}$ & $0.021 \mathrm{a}$ & $0.018 \mathrm{a}$ & 28.21 \\
\hline
\end{tabular}

Distinct letters in the row indicate significant differences according to Tukey's test $(\mathrm{P} \leq 0.05)$.

DAT: Days after transplanting, LA: total leaf area, LWR: leaf weight ratio, SLM: specific leaf mass, OY: oil yield.
Table 5. Dry mass parameters and essential oil from the second cut (120 DAT) of Melissa officinalis plants under different colored nets.

\begin{tabular}{|c|c|c|c|c|c|}
\hline & Full sun & Black & Blue & Red & $\mathrm{CV}(\%)$ \\
\hline $\mathrm{LA}, \mathrm{dm}^{2}$ & $16.80 \mathrm{c}$ & $32.93 \mathrm{~b}$ & $45.03 \mathrm{a}$ & $32.70 \mathrm{~b}$ & 14.92 \\
\hline Leaf DM, g & $8.49 \mathrm{~b}$ & $10.24 \mathrm{ab}$ & $11.87 \mathrm{a}$ & $11.37 \mathrm{ab}$ & 14.09 \\
\hline Stem DM, g & $5.29 \mathrm{~b}$ & $8.78 \mathrm{a}$ & $9.19 \mathrm{a}$ & $10.50 \mathrm{a}$ & 15.74 \\
\hline Root DM, g & $20.59 b$ & $23.49 \mathrm{~b}$ & $21.88 \mathrm{~b}$ & $33.16 \mathrm{a}$ & 16.78 \\
\hline Total DM, g & $34.37 \mathrm{~b}$ & $42.53 \mathrm{ab}$ & 42.94ab & $55.04 \mathrm{a}$ & 14.56 \\
\hline LWR, $\mathrm{g} \mathrm{g}^{-1}$ & $0.24 \mathrm{~b}$ & $0.24 \mathrm{~b}$ & $0.27 \mathrm{a}$ & $0.20 \mathrm{c}$ & 6.02 \\
\hline Root/Shoot, $\mathrm{g} \mathrm{g}^{-1}$ & $1.50 \mathrm{ab}$ & $1.23 \mathrm{ab}$ & $1.03 \mathrm{~b}$ & $1.51 \mathrm{a}$ & 11.51 \\
\hline SLM, $\mathrm{g} \mathrm{dm}^{-2}$ & $0.51 \mathrm{a}$ & $0.30 \mathrm{~b}$ & $0.26 \mathrm{~b}$ & $0.34 \mathrm{~b}$ & 11.95 \\
\hline Height, $\mathrm{cm}$ & $20.2 \mathrm{c}$ & $37.2 \mathrm{~b}$ & $43.8 \mathrm{a}$ & $34.2 \mathrm{~b}$ & 7.86 \\
\hline Essential oil content, \% & $0.52 \mathrm{a}$ & $0.39 b$ & $0.41 \mathrm{ab}$ & $0.15 \mathrm{c}$ & 20.33 \\
\hline OY, g plant ${ }^{-1}$ & $0.030 \mathrm{~b}$ & $0.039 \mathrm{ab}$ & $0.052 \mathrm{a}$ & $0.010 \mathrm{c}$ & 21.82 \\
\hline
\end{tabular}

Distinct letters in the row indicate significant differences according to Tukey's test $(\mathrm{P} \leq 0.05)$.

DAT: Days after transplanting, LA: total leaf area, LWR: leaf weight ratio, SLM: specific leaf mass, OY: oil yield.

photosynthesis rate per unit of LA, which is a characteristic of shade leaves (Souza et al., 2011; Meira et al., 2012).

All lemon balm plants grown under colored nets showed higher total biomass in the second cut compared to plants grown in full sunlight, with the red net presenting the most improved value (Table 5). Better plant growth using red net was also observed in Catharanthus roseus (L.) G. Don (Melo and Alvarenga, 2009). The leaves of plants grown under red net may have benefited by the greater availability of red radiation (above $590 \mathrm{~nm}$ ), which is more efficient for the performance of photochemical step of photosynthesis (Henrique et al., 2011). However, this pattern of response cannot be generalized, since the effect of radiation is dependent on the plant species (Braga et al., 2009). For example, plants of $M$. xpiperita showed no difference in total biomass between full sunlight and red net growth conditions (Costa et al., 2012).

The higher photosynthetic capacity $\left(A_{\max }\right)$ in lemon balm plants under full sunlight was not converted into higher dry mass, possibly because the energy content may have been stored as starch in the leaves, as suggested by Brant et al. (2011). In addition, plants subjected to the full sunlight treatment must develop mechanisms to avoid cell damage under high irradiance condition (Gonçalves et al., 2012), which may result in greater energy expenditure for maintenance of cellular structures, increased carbohydrate consumption and, as consequence, decreased dry mass accumulation.

The LWR at 120 DAT was superior in plants grown under blue net in relation to the other treatments (Table 5), indicating that DM accumulation was relatively higher in leaves than other parts of the plant. The use of colored nets did not affected the root/shoot ratio in comparison to plants grown in full sunlight (Table 5). However, it appears that the quality of light can change the allocation of biomass, as there was an increase in the DM distribution to the roots in plants grown under red net compared to plants under blue net. Plants in full sunlight showed the highest value of specific leaf mass (SLM) (Table 5), which may be indicative of thicker leaves, resulting in higher DM per leaf area. 
The regrowth of the plants after the first cut was more pronounced in plants under blue net than the plants in full sunlight as the former treatment resulted in greater height at 120 DAT (Table 5). Similar result was observed in $O$. gratissimum (Martins et al., 2008) and M. laevigata (Souza et al., 2011) grown under blue net. As phytochrome and other photoreceptors absorb light in the blue region of the spectrum, which in turn causes differential responses in phototropism, growth and morphogenesis (Smith, 1982), the increased height in lemon balm plants may be due to higher blue/red ratio provided by the blue net.

There was nonsignificant effect of the colored nets on the production of essential oil in leaves in the first cut of lemon balm (Table 4). However, in the second cut, after $70 \mathrm{~d}$ of plant regrowth, a significant reduction in the content and yield of essential oil was observed in the leaves of plants grown under red net (Table 5), which corroborates the results presented by Brant et al. (2009). According to these authors, the change in the incident spectrum promoted by red net would cause the lack of another wavelength that is not absorbed by photosynthetic pigments and provokes cancellation of any major route for the synthesis of terpenes interfering in the production of essential oil. On the other hand, the use of blue net resulted in a $30 \%$ higher essential oil yield (Table 5), which is consistent with the highest values of plant height and LA seen in this treatment. Our results are in agreement with Martins et al. (2008), who showed that $O$. gratissimum plants under blue net were taller and had higher essential oil content.

Changes in the amount and quality of light imposed by colored nets did not result in noticeable anatomical differences in lemon balm plants compared to the full sunlight grown plants. Only a slight, but nonsignificant increase was detected in the values of the anatomical parameters in leaves of plants under or the blue net (Table 6).

\section{CONCLUSION}

Melissa officinalis plants grown under shade from blue net showed the highest essential oil yield as a result of superior plant height and leaf area at 120 DAT. On the other hand, the

Table 6. Leaf anatomy characteristics of Mellisa officinalis plants under different colored nets.

\begin{tabular}{lrrrrr}
\hline Treatment & Full sun & Black & Blue & Red & CV (\%) \\
$\mathrm{ET}_{\mathrm{ad}}, \mu \mathrm{m}$ & $23.17 \mathrm{a}$ & $22.59 \mathrm{a}$ & $30.12 \mathrm{a}$ & $26.06 \mathrm{a}$ & 22.53 \\
$\mathrm{ET}_{\mathrm{ab}}, \mu \mathrm{m}$ & $15.71 \mathrm{a}$ & $13.70 \mathrm{a}$ & $16.11 \mathrm{a}$ & $14.72 \mathrm{a}$ & 24.37 \\
$\mathrm{PPT}, \mu \mathrm{m}$ & $53.46 \mathrm{a}$ & $44.33 \mathrm{a}$ & $42.59 \mathrm{a}$ & $49.10 \mathrm{a}$ & 17.49 \\
$\mathrm{SPT}, \mu \mathrm{m}$ & $53.29 \mathrm{a}$ & $53.45 \mathrm{a}$ & $62.93 \mathrm{a}$ & $47.70 \mathrm{a}$ & 27.42 \\
$\mathrm{LT}, \mu \mathrm{m}$ & $144.97 \mathrm{a}$ & $132.87 \mathrm{a}$ & $151.16 \mathrm{a}$ & $136.00 \mathrm{a}$ & 13.82 \\
$\mathrm{VD}, \mathrm{mm} \mathrm{mm}{ }^{-2}$ & $5.53 \mathrm{a}$ & $5.66 \mathrm{a}$ & $5.26 \mathrm{a}$ & $4.87 \mathrm{a}$ & 14.99 \\
$\mathrm{~N}^{\circ} \mathrm{CM}$ & $63.75 \mathrm{a}$ & $76.25 \mathrm{a}$ & $84.00 \mathrm{a}$ & $76.00 \mathrm{a}$ & 25.27
\end{tabular}

Distinct letters in the row indicate significant differences according to Tukey's test $(\mathrm{P} \leq 0.05)$.

$\mathrm{ET}_{\mathrm{ad}}$ and $\mathrm{ET}_{\mathrm{ab}}$ : Adaxial and abaxial epidermis thickness, PPT: palisade parenchyma thickness, SPT: spongy parenchyma thickness, LT: leaf thickness, VD: venation density, $\mathrm{N}^{\circ} \mathrm{CM}$ : total number of conduits of the midrib. use of red net resulted in a reduction in the yield of essential oil in leaves. In addition, no anatomical changes were detectable in response to modifications in the quantity and quality of light energy that reaches the plants of $M$. officinalis. The comparatively low biomass produced by plants cultivated under full sunlight, and consequently low essential oil content, suggests that assimilates might have been directed to the maintenance and repair mechanisms necessary to support high irradiance conditions. Finally, our data showed that the photo-selective shade provided by the blue net could be incorporated into the protected cultivation practices currently used for producing M. officinalis essential oil.

\section{ACKNOWLEDGEMENTS}

The authors thanks Coordenação de Aperfeiçoamento de Pessoal de Nível Superior (CAPES) for the grant of scholarship to the first author.

\section{REFERENCES}

Blum, A. 2009. Effective use of water (EUW) and not water-use efficiency (WUE) is the target of crop yield improvement under drought stress. Field Crops Research 112:119-123.

Braga, F.T., M. Pasqual, E.M. Castro, S.L. Dignart, G. Biagiotti, e J.M.P. Porto. 2009. Qualidade de luz no cultivo in vitro de Dendranthema grandiflorum cv. Rage: características morfofisiológicas. Ciência e Agrotecnologia 33:502-508.

Brant, R.S., J.E.B.P. Pinto, L.F. Rosal, C.J.B. Albuquerque, P.H. Ferri, e R.M. Corrêa. 2009. Crescimento, teor e composição do óleo essencial de melissa cultivada sob malhas fotoconversoras. Ciência Rural 39:1401-1407.

Brant, R.S., J.E.B.P. Pinto, L.F. Rosal, C. Alves, C. Oliveira, e C.J.B. Albuquerque. 2011. Adaptações fisiológicas e anatômicas de Melissa officinalis L. (Lamiaceae) cultivadas sob malhas termorrefletoras em diferentes intensidades luminosas. Revista Brasileira de Plantas Medicinais 13:467-474.

Brant, R.S., J.E.B.P. Pinto, L.F. Rosal, E.M. Castro, C. Oliveira, e C.J.B. Albuquerque. 2010. Características fisiológicas e anatômicas de Melissa officinalis L. (Lamiaceae) cultivadas sob diferentes condições de luminosidade. Magistra 22:146-152.

Brazil. 1992. Ministério da Agricultura e Reforma Agrária. Normas Climatológicas de 1961 - 1990. Secretaria Nacional de Irrigação/ Departamento Nacional de Meteorologia, Brasília, Brasil.

Cassol, D., A.R. Falqueto, e M.A. Bacarin. 2007. Fotossíntese em Mentha piperita e Melissa officinalis sob sombreamento. Revista Brasileira de Biociências 5:576-578.

Costa, A.G., J.H. Chagas, J.E.B.R. Pinto, e S.K.V. Bertolucci. 2012. Crescimento vegetativo e produção de óleo essencial de hortelãpimenta cultivada sob malhas. Pesquisa Agropecuária Brasileira 47:534-540

Ferreira, D.F. 2000. Análises estatísticas por meio do Sisvar para Windows versão 4.0. Universidade Federal de Lavras (UFLA), Departamento de Ciências Exatas (DEX), Lavras, Minas Gerais, Brasil.

Fonseca, L.C.M., C.E.B. Proença, e E.G. Gonçalves. 2007. Descrição do padrão de venação foliar em Sparthicarpa Hook (Araceae). Acta Botânica Brasílica 21:213-221.

Gonçalves, J.F.C., C.E.M. Silva, G.C. Justino, e Nina Junior. 2012. Efeito do ambiente de luz no crescimento de plantas jovens de mogno (Swietenia macrophylla King). Scientia Forestalis 40:337-344. 
Henrique, P.C., J.D. Alves, S. Deuner, P.F.P. Goulart, e D.E. Livramento. 2011. Aspectos fisiológicos do desenvolvimento de mudas de café cultivadas sob telas de diferentes colorações. Pesquisa Agropecuária Brasileira 46:458-465.

Johansen, D.A. 1940. Plant microtechnique. McGraw Hill, New York, USA.

Lichtenthaler H.K., and S. Burkart. 1999. Photosynthesis and high light stress. Bulgarian Journal of Plant Physiology 25:3-16.

Lichtenthaler, H.K., C. Buschmann, M. Doll, H.-J. Fietz, T. Bach, U. Kizel, et al. 1981. Photosynthetic activity, chloroplast ultrastructure, and leaf characteristics of high-light and low-light plants and of sun and shade leaves. Photosynthesis Research 2:115-141.

Martins, J.R., A.A. Alvarenga, E.M. Castro, J.E.B.P. Pinto, e A.P.O. Silva. 2008. Avaliação do crescimento e do teor de óleo essencial em plantas de Ocimum gratissimum L. cultivadas sob malhas coloridas. Revista Brasileira de Plantas Medicinais 10:102-107.

Meira, M.R., E.R. Martins, e A.S. Manganotti. 2012. Crescimento, produção de fitomassa e teor de óleo essencial de melissa (Melissa officinalis L.) sob diferentes níveis de sombreamento. Revista Brasileira de Plantas Medicinais 14:352-357.

Melo, A.A.M., e A.A. Alvarenga. 2009. Sombreamento de plantas de Catharanthus roseus (L.) Don 'Pacifica White' por malhas coloridas: desenvolvimento vegetativo. Ciência e Agrotecnologia 33:514-520

O'Brien, T.P., N. Feder, and M.E. McCully. 1965. Polychromatic staining of plant cell walls by toluidine blue. Protoplasma 59:368-373.
Oliveira, M.I., E.M. Castro, L.C.B. Costa, e C. Oliveira. 2009. Características biométricas, anatômicas e fisiológicas de Artemisia vulgaris L. cultivada sob telas coloridas. Revista Brasileira de Plantas Medicinais 11:56-62.

Oliver, R.J., J.W. Finch, and G. Taylor. 2009. Second generation bioenergy crops and climate change: a review of the effects of elevated atmospheric $\mathrm{CO}_{2}$ and drought on water use and the implications for yield. CGB Bioenergy 1:97-114.

Oren-Shamir, M., E.E. Gussakovsky, E. Shpiegel, A. Nissim-Levi, K. Ratner, R. Ovadia, et al. 2001. Coloured shade nets can improve the yield and quality of green decorative branches of Pittosporum variegatum. Israel Journal of Horticultural Science and Biotechnology 76:353-361

Poudel, P.R., I. Kataoka, and R. Mochioka. 2008. Effect of redand blue-light emitting diodes on growth and morphogenesis of grape. Plant Cell Tissue and Organ Culture 92:147-153.

Smith, H. 1982. Light quality photoperception and plant strategy. Annual Review of Plant Physiology 33:481-518.

Souza, G.S., E.M. Castro, A.M. Soares, A.R. Santos, e E. Alves. 2011. Teores de pigmentos fotossintéticos, taxa de fotossíntese e estrutura dos cloroplastos de plantas jovens de Mikania laevigata Schultz Bip. Ex Baker cultivadas sob malhas coloridas. Semina Ciências Agrárias 32:1843-1854 (Sup. 1).

Valladares, F., and Ü. Niinemets. 2008. Shade tolerance, a key plant feature of complex nature and consequences. Annual Review of Ecology, Evolution, and Systematics 39:237-257.

Weitzel, C., and M. Petersen. 2010. Enzymes of phenylpropanoid metabolism in the important medicinal plant Melissa officinalis L. Planta 232:731-742. doi:10.1007/s00425-010-1206-x. 